VITIATION OF THE USE TAX:

\title{
IT PAYS TO ADVERTISE
}

I

IN THE MID-I930's, various pressures compelled the recognition and utilization of the sales tax as a valuable source of revenue. ${ }^{1}$ Consequently, it became necessary to protect the tax from various channels of evasion, the most significant of which was the loss due to out-of-state purchases, since such transactions were immune from sales tax under a settled rule of constitutional law. ${ }^{2}$ A separate tax imposed on the $u s e^{3}$ of personal property within the taxing state was conceived as the ideal device for reaching goods purchased out-of-state ${ }^{4}$ and brought into the state for use. ${ }^{5}$

\footnotetext{
${ }^{2}$ See Criz, The Use TAX I (r94I).

${ }^{2}$ The rule was that states were impliedly prohibited by the Commerce Clause from taxing interstate sales. Brown v. Maryland, 12 Wheat. 419 (U.S. 1827). However, the scope of this prohibition was substantially limited when the Supreme Court, in I940, held that the local delivery in an interstate sale of goods was sufficient local activity to sustain a sales tax by the buyer's state. McGoldrick v. Berwind-White Coal Mining Co., 309 U.S. 33 (1940); see Powell, Neww Light on Gross Receipts Taxes, 53 Harv. L. REv. 909 (1940).

${ }^{3}$ As is indicated by its title, the use tax is a levy on the use or enjoyment of that which is purchased, while a sales tax is a tax on the freedom of purchase. McLeod v. J. E. Dilworth Co., 322 U.S. 327, 330 (1944). [Curiously, the Supreme Court in a case decided the same day as the Dilworth case, referred to the two taxes as being the same in substance and the same in their effect on interstate commerce. International Harvester Co. v. Department of Treasury, 322 U.S. 340, 347 (1944).] Further, the use tax is an ad valorem tax-the value of the property used, stored, or consumed being determinative as to tax liability; and it is non-recnrring-the taxing state levying only once on a given piece of property, in contrast to annual license or property taxes. For a thorough discussion of the tax from an economist's point of view, see CRIZ, supra note $\mathrm{I}$.

"Theoretically, the use tax is not restricted in its scope to personal property purchased outside the taxing state. Rather, all personal property used, stored, or consumed within the taxing state is subject to the tax. However, all the use tax statutes exempt commodities on which a sales tax has already been paid, restricting the use tax, in practice, to out-of-state purchases. But the absence of this exemption would give vent to the inherent scope of the tax, which includes all commodities used within a state irrespective of the state of purchase. CRIZ, supra note I, at 3 .

${ }^{5}$ It has been contended that the protection of sales tax revenues is not, in itself, sufficient to justify the use tax. The thought is that "the amount of diversion due to the sales tax is quite small and the corresponding loss of revenue negligible." Carlson, Interstate Barrier Effects of the Use Tax, 8 LAW \& CoNTEMP. Prop. 223, 224 (194x). Because of this inherent weakness of the "revenue protection" theory, the justification for the use tax most generally advanced is that it furnishes protection to local merchants. In particular, local retailers of large items are benefited by the use tax, since the sales tax on such items is sufficiently large to induce purchasers to incur the incon-
} 
Unfortunately, there is implicit in the nature of the use tax a pronounced problem of collection. ${ }^{6}$ The source of the difficulty is apparent. It is virtually impossible to impose a workable check upon the numerous out-of-state purchases which may be made by individuals in the course of a year. While such - a check might conceivably succeed as applied to items of large size or those for the possession of which a registration is required, it would unquestionably fail as applied to small day-to-day purchases of consumable goods. ${ }^{7}$ The only workable solution would seem to be a procedure similar to that used under the sales taxto collect the tax from the out-of-state retailer, leaving him to reimburse himself from the consumer. ${ }^{8}$ This, in fact, has been the procedure adopted by use tax agencies whenever possible.

venience of out-of-state shopping in an attempt to avoid the tax. However, in the light of the Berwind-White decision, note 2 supra, it has been suggested that the use tax is no longer necessary. Brown, Future of Use Taxes, 8 Law \& Contemp. Prob. 495, 504 (194I). At the other extreme, however, is the thought that since the scope of the use tax is broader than that of the sales tax, the latter should be abandoned and the use tax imposed in its place. Powell, supra note 2, at 930.

${ }^{\circ}$ Other problems have been overcome. The constitutionality of the use tax was settled in 1937 in a case arising from the objection of a Washington construction company to paying the tax on goods purchased out of state. The tax was assailed as a direct burden on interstate commerce and as a protective tariff. The Supreme Court, however, upheld the tax as a levy on the local incident of use after shipment in commerce and unrelated to the act of importation. Henneford v. Silas Mason Co., 300 U.S. 577 (1937).

Also settled is the invalidity of a use tax on articles being used, when taxed, in interstate commerce, such as the fuel used to propel a boat travelling between two states. Helson \& Randolph v. Kentucky, 279 U.S. 245. (1929). However, the principle of the Helson case was not extended to articles merely destined for use in interstate commerce. The Supreme Court subsequently held that the storage of property within a state is a taxable event, notwithstanding the pendency of consumption in interstate commerce. Nashville, C. \& St. L. Ry. v. Wallace, 288 U.S. 249 (1933); Edelman v. Boeing Air Transport, Inc., 289 U.S. 249 (1933). Eventually, the Supreme Court reduced the break in interstate movement necessary to sustain a use tax to the brief pause between the delivery of articles to their destination and the completion of installations necessary for their use in interstate commerce. Pacific Tel. \& Tel. Co. v. Gallagher, 306 U.S. 182 (1939); Southern Pac. Co. v. Gallagher, 306 U.S. 167 (1939).

${ }_{7}$ Having recognized the impracticability of collecting the $\operatorname{tax}$ on the use of such items, many states have exempted them from tax liability, thereby removing the ordinary small purchaser from the category of tax evader. See, e.g., MicH. Comp. Laws $\S 205.94(\mathrm{k})$ (rg48):

${ }^{8}$ In the light of such a reimbursement plan, the incidence of both use and sales taxes has been categorically assumed to fall on the consumer. But there is abundant economic authority contradicting the inevitability of such a shift. See Warren \& Schlesinger, Sales and Use Taxes: Interstate Commerce Pays Its Way, 38 CoLuM. L. REv. 49,71 (1938). It has even been suggested that a notoriously non-shifted sales tax (i.e., seller pays tax without being reimbursed) might invalidate a shifted use tax 
The availability of the out-of-state retailer as a collection agent, however, has been seriously restricted by the recent case of Miller Bros. v. Maryland. ${ }^{3}$ There, the defendant, a Delaware retailer, having been directed by the state of Maryland to collect its use tax ${ }^{10}$ on sales made to Maryland purchasers, had refused on the ground that Maryland lacked authority to compel it to do so. The Maryland Supreme Court sustained the state in an action which had been brought to recover these taxes, ${ }^{11}$ but the United States Supreme Court, by a vote of 5-4, reversed, holding that advertising and delivering in Maryland were not sufficient contacts within the state to require the Delaware retailer's compliance with Maryland's requests. In dissenting, Justice Douglas, with whom the Chief Justice and Justices Black and Clark concurred, mildly opined otherwise. ${ }^{12}$ The significance of this decision and its implications for tax administration can be appreciated only when viewed in context with the long line of decisions which it supplements.

The basic authority on which the constitutionality of the out-of-state retailer collection device rests is Pierce Oil Corp. v. Hopkins. ${ }^{13}$ There, a local retailer had defied the mandate of an Arkansas statute ${ }^{14}$ which required him to collect a tax on the sale of gasoline to be used in motor vehicles on highways of the state. His contention that the burden and expense which collection of the tax would impose upon him contravened the due process clause of the Fourteenth Amendment was rejected, however, on the ground that such inconveniences were merely incidental to a proper exercise of the state's regulatory powers. ${ }^{15}$ Relying primarily on this case, ${ }^{16}$ the Supreme Court upheld the application of a similar Iowa statute ${ }^{17}$ to an Arizona corporation "doing business". in Iowa in Monamotor Oil Co. v. Johnson, ${ }^{18}$ observing somewhat gratuitously that the requirement by a state that an out-of-state corporation

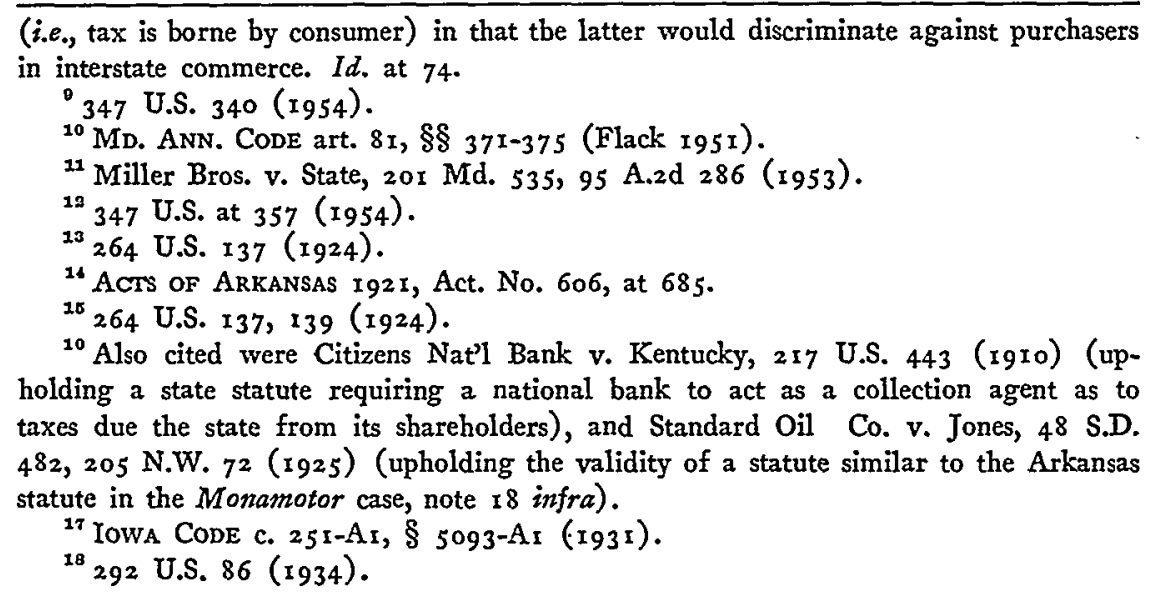


collect its use tax was " $a$ common and entirely lawful arrangement." Any lingering doubts as to the constitutionality of this tax collection device were dispelled by Felt $\mathcal{E}$ Tarrant Mfg. Co. v. Gallagher. ${ }^{20}$ There, an Illinois retailer not qualified to do business in California, had solicited orders for goods from California purchasers through local offices maintained for that purpose. California's attempt to compel the Illinois retailer to collect its use $\operatorname{tax}^{21}$ on these sales, however, was met this time with the added contention that such an imposition would constitute an undue burden on commerce. But the Supreme Court, relying almost entirely on the Monamotor case, summarily brushed this argument aside and sustained the collection device, noting that it "imposes no unconstitutional burden either upon interstate commerce or upon the appellant."22

Emboldened by these successes, legislatures, seeking to tap new revenue sources, then sought further to extend the reach of the out-ofstate retailer collection device by requiring every retailer maintaining $a$ place of business within the state to collect the tax from local purchasers, even where the sale had been consummated outside of the state. ${ }^{23}$ The validity of such provisions was examined in the companion cases of Nelson v. Sears, Roebuck $\mathcal{E}^{3} \mathrm{Co}^{24}{ }^{24}$ and Nelson v. Montgomery Ward $\mathcal{E}^{2} \mathrm{Co}^{25}$ There, defendants, foreign corporations maintaining places of business in Iowa, had been subjected to the duty of tax collection of mail order transactions involving orders sent by Iowa purchasers to out-of-state branches of the companies, and filled by mail or by common carrier from these branches. The defendants contended, inter alia, that the Monamotor and Felt-Tarrant cases were distinguishable in that the foreign corporations there involved had been actively engaged in a local business, whereas in the instant cases the defendants, though they did incidentally maintain local branches, were required to collect the use tax on transactions arising entirely independently of the places of business in Iowa. In addition, the defendants urged the unfairness of saddling them with the burdensome expenses of collection, one of which was the liability for those taxes not remitted by purchasers. ${ }^{26}$ The Supreme Court rejected these and other arguments,

${ }^{10}$ Id. at 93. ${ }^{20} 306$ U.S. 62 (1939).

${ }^{21}$ CAL. STAT. c. 361 (1935), as amended, CAL. Stat. cc. 401, 67x, 683 (1937).

22306 U.S. 62,68 (1939).

${ }^{23}$ See, e.g., IOWA CODE $\$ \S 6943.102,6943.125$ (1939).

24312 U.S. 359 (1941).

25312 U.S. 373 (1941).

${ }^{20}$ On the basis of experience in use tax collecting in Illinois, Sears, Roebuck \& Co. introduced evidence tending to prove that the minimum loss it could expect in undertaking to collect the Iowa use tax would amount to about $\$ 45,700$ on every $\$ 100,000$ of use tax liability. 312 U.S. 359,365 (1941). 
however, and affirmed the duty of the defendants to collect the use tax, observing that, irrespective of the company branches involved in these mail orders, Iowa might assume their relation to the defendants' outlets within the state. As to the expense of collecting the tax, the Court would not permit appellees to "found a constitutional right on the practical opportunities for tax avoidance which its method of doing business affords Iowa residents. . ...27

A further extension of the out-of-state retailer collection device was countenanced by the Supreme Court in General Trading Co. v. State Tax Commission of Iowa. ${ }^{28}$ There, the defendant, a Minnesota corporation which had not qualified to do business in Iowa and maintained no offices there, had solicited orders and made sales of goods to Iowa purchasers through traveling salesmen sent into Iowa from the headquarters in Minnesota, and had delivered the goods by mail or common carrier. In upholding the defendant's duty to collect Iowa's use tax the Court cited the Felt-Tarrant case as an indistinguishable precedent, and purported to follow the Sears Roebuck, Montgomery $W$ ard, and Monamotor cases. It seemingly ignored the fact that in these cases the out-ofstate vendor had either qualified to do business within the taxing state, or at least had maintained offices there; the defendant here had done neither. Mr. Justice Jackson seized upon this distinction in a vigorous dissent, in which he stated that "this decision, by which one may not ship goods from anywhere in the United States to a purchaser in Iowa without becoming a non-resident tax collector, exceeds everything so far done by this court."29

Concededly, the Court might have been justified in deciding several of these cases differently. That it did not, in the face of substantial due process and interstate commerce objections, indicates the significance which it has attached to the preservation and extension of this collection device. In the light of this obvious choice of policy, therefore, the Miller Bros. decision is surprising. Despite the manifest consistency with the past decisions, from a standpoint of policy, of the extension sought, and despite the national significance of the question, ${ }^{30}$ a sharply

${ }^{27}$ Id. at 366 .

${ }^{28} 322$ U.S. 335 (1944).

${ }^{20}$ Id. at 339 .

${ }^{30}$ This "national significance" derives in part from the fact that the decision determined the invalidity of various state statutory provisions specifically recognizing solicitation and local delivery as adequate contacts to sustain the collection device. E.g., ALA. CODE tit. 51, $\$ 790$ (I940); N.C. GeN. STAT. I05-223, § 805 (1950); Miss. Code ANN. $\S$ ror46-02(10) (1942). But a broader significance appears when the Miller Bros. case is viewed in the context of the tax scheme to which it applies. Sales tax revenues are, in many states, so substantial as to justify partial or total abandonment of the state income tax. Fairness and necessity dictate to each citizen-purchaser 
divided court was "unable to find ... a precedent for sustaining the liability asserted by Maryland here."31 Though it had countenanced more substantial extensions of the out-of-state retailer collection device, the relatively mild advances beyond personal sales solicitation to solicitation through media was apparently more than the Court would tolerate.

Though the distinction established by this case may seem to be illogical and unreasonable, it is nevertheless determinative as to the powers of tax administrators. Hereafter, with a lesser degree of activity than solicitation by salesmen within the taxing state, the out-of-state retailer collection device can be expected to fall as violative of the due process clause of the Fourteenth Amendment.

GARY S. STEIN

an obligation to pay taxes; but such deterrents to tax avoidance as the out-of-state retailer collection device are needed to enforce this obligation. The Miller Bros. decision vitiates the use tax by immunizing therefrom purchases from out-of-state stores (many of which typically deliver and advertise in the taxing state but rarely send salesmen there) and thus pointedly frustrates an element of the states' tax programs. That state tax programs should be sustained whenever possible is axiomatic. It seems incomprehensible, then, that the out-of-state retailer collection device, clearly an integral part of Maryland's tax scheme, should be emasculated on the basis of the rather fine distinction between personal sales solicitation and solicitation through media.

${ }^{31} 347$ U.S. 340,345 (1954). 